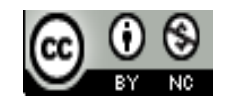

Journal of Education, Teaching, and Learning is licensed under

a Creative Commons Attribution-Non Commercial 4.0 International License.

\title{
The Local Wisdom of Sambas Malay Ethnic Assessed from Character Mathematical Connections
}

\author{
Bistari \\ Universitas Tanjungpura, Pontianak, Indonesia \\ E-mail: bistari.bs@gmail.com
}

\begin{abstract}
The local wisdom of the Sambas Malay ethnic from generation to generation in this study are 12 species. Among the 12 are two local wisdom that is almost extinct ie behind the mat and ngukor. This study aims to obtain information and describe related local wisdom ethnic Malay Sambas studied in mathematical connection. The method used in this research is descriptive qualitative. Data obtained through questionnaires and interviews on the parties concerned. The result of the research shows that there are 12 local wisdom of Melayu Sambas ethnic that ever exist in social life, and that is still realized 10 local wisdom (except ngukor and pacoan). While the local wisdom of Malay Sambas ethnic who have relevance to the mathematical connection and strengthening the education of social and environmental care characters there are 10 kinds. To categorize and pacoan pertained weak connection relevance.
\end{abstract}

Keywords: Local Wisdom; Malay Ethnic; Mathematical Connection; Character

\section{INTRODUCTION}

Based on the observation of the researchers (March, 2012) in the process of learning in the classroom at 12 junior high schools in Sambas, followed by question and answer to teachers and learners, revealed some things related to the learning process. Some things can be expressed as follows: (1) $75 \%$ of teachers dominate the learning process in the classroom; (2) the emphasis of learning is largely on the symbolic, and (3) the lack of digging up mathematical connections. Minimal student involvement, this is one of the causes of students acting to accept what it is. Critical attitude of students less get the portion, because the teacher is less and even not conditioned student involvement in learning. The involvement of students can be interpreted as students play an active role as participants in the learning process. According to Dimyati and Mudjiono (1994: 56-60), student activeness can be driven by the teacher's role. Teachers strive to provide opportunities for active students, both actively seeking, processing and managing their learning achievement.

The result of Setyawan's research study (2013: 109) concludes that the improvement of students' mathematical connection ability can be enhanced by the ConnectingOrganizing-Reflecting-Extending model. This resulted in a student's ability to link his own experience of mathematical ideas to a better and lasting understanding of mathematics because he can see the interrelationships between concepts in mathematics, with non-mathematical contexts, and with daily life experiences (NCTM, 2000: 64).
Weaknesses in mathematical connections can result in the ability to solve stories. A person's mathematical connection is one of the competencies in solving mathematical problems. Dwi Astuti and Bambang Hudiono (2009) examined mathematical solving abilities in 4 ethnic groups in West Kalimantan. It was concluded that the mean score of basic ability and problem solving for the four ethnic groups is not identical. From Post Hoc Test result concluded that the ability of problem solving of ethnic Chinese mathematic with Dayak ethnic and between ethnic Dayak with ethnic Malays have significant difference of mean score. It can be said that alleged mathematical connection competence is influenced by ethnic origin.

The Sambas Malay ethnic group has some local wisdom and some of them are ethnomathematics. Among the ethnomathematics and reveals local wisdom that is bersaprah, flour, bepapas, game gasing, the mention of unit weight, the mention of the unit length, and so forth. The results of Srihayati et al. (2011) concluded that the local wisdom of "inhaled papagong" and "pikukuh", are the values of environmental wisdom that can form the values of responsibility for the Baduy community. Not much different from the local wisdom Malay-owned Sambas, of course, if studied further try to instill the value of responsibility. With respect to mathematical concepts, the procedure/rules of conduct take into account time, many, specific weight and length, adjusted to the prevailing customs.

Through this study, it is expected that the local wisdom of Malay Sambas can be revealed and realized in the 
learning process in the classroom. The long-term goal is the local wisdom of Melayu Sambas from the point of view of mathematical concepts can be archived through mathematics improvement supplements. So that learners learn math by way of mind and heart. The peculiarity and pride that is considered noble to a cultural heritage need to be expressed and reintroduced. This activity is an alternative to avoid "cultural erosion".

Understanding local wisdom (local wisdom) in the dictionary consists of two words: wisdom (wisdom) and local (local). Local means local, while wisdom (wisdom) is the same as wisdom. In general, local wisdom (local wisdom) local ideas that are wise, full of wisdom, good value, which is embedded and followed by members of the community.

The results of the Phongphit (2002) study reveals: Local wisdom in Bangkhunsai can be observed in the traditional ways of life, such as occupations, relationships within communities, and spiritual beliefs and practices, and serves to promote an honest, fair, and sustainable use of natural resources. This is a description that local wisdom that reflects the traditional can be interpreted as a cultural policy of habituation that is considered good by the local community. This habit can bring up honesty, mutual help, and help each other.

In this study, the variety of local wisdom traced the implementation procedure so that the presence or absence of mathematical concepts contained in the variety of local wisdom can be ascertained. The content of mathematical concepts is then associated with a mathematical connection. If possible, it can be expressed by students who are applying the related mathematical concepts.

Without a mathematical connection, students must learn and remember too many mutually exclusive concepts and procedures (NCTM, 2000: 275). In a study, it was found that students were often able to register mathematical concepts related to real problems, but few students were able to explain why the concept was used in the application (Lembke and Reys 1994, cited Bergeson, 2000: 38). Thus the ability to connect needs to be trained to school students. If students are able to associate mathematical ideas then their math comprehension will deepen and last longer as they are able to see interrelationships between topics in mathematics, with contexts other than mathematics, and with the experience of daily living (NCTM, 2000: 64).

In addition to the connection being studied, the effect on the characters that affect the student experience in mathematical connection also becomes a study. Strengthening character education relevant to the theme of this study is environmental and social care. Thus, it is hoped that the study of local wisdom of Sambas Malay from the aspect of mathematical connection can form the strengthening of character education from the environmental and social care aspects.

\section{RESEARCH METHOD}

In this study, researchers used a qualitative approach where in this study more emphasis on the meaning and process rather than the results of an activity. Qualitative research aims to examine the world of meaning expressed through the behavior of society according to the perspective of society itself.

The study was conducted in Kecamatan Jawai Sambas District. The type of research used by researchers is a qualitative descriptive type that studies the problems that exist and work procedures that apply to every variety of local wisdom. The incident that will be described is an event that occurs today according to the observation. Also, a previous incident, obtained through interviews with traditional leaders.

At this stage of the research to obtain valid and accountable data, it can be obtained through (a) interview, (b) direct observation, and (c) document. The interviews conducted are unstructured interviews, which in this method allows the question to be flexible, the questions are more open, stay focused, so that the information obtained is rich and the conversation is not rigid. For direct observation is the way of data collection by way of recording carefully and systematically. While the document, the process of looking back the data sources of existing documents and can be used to expand the data that has been found (Masri and Efendi, 1999: 72).

\section{RESULT AND DISCUSSION}

\section{Data Research Results}

Several types of local wisdom were obtained during the interview on July 15, 2014, and the sessions of several kinds of literature were revealed among others: kinship system, cikram, antar pinang, marriage implementation, waste, turning mat, saprah, tarup, pacoan. Among the types of local wisdom that still survive to date is associated with the crowd. Such as the implementation of marriage, saprahan dinner, fresh flour, and pacoan. However, the activity is not as vibrant as it was 20 years ago. The following data from the study of local wisdom of Malay Sambas in the form of tables.

Table 1

Linkage of Local Wisdom to Mathematics Concept 


\begin{tabular}{|c|c|}
\hline $\begin{array}{l}\text { Variety of } \\
\text { Local } \\
\text { Wisdom } \\
\end{array}$ & Definition \\
\hline $\begin{array}{l}\text { Kinship } \\
\text { system }\end{array}$ & $\begin{array}{l}\text { The bilateral or bilateral system is to take the lineage } \\
\text { of the father and mother }\end{array}$ \\
\hline Cikram & Sign of engagement bond between two human beings \\
\hline $\begin{array}{l}\text { Antar } \\
\text { pinang }\end{array}$ & Delivery of goods \\
\hline $\begin{array}{l}\text { The } \\
\text { wedding }\end{array}$ & A crowd show with a bridal match \\
\hline $\begin{array}{l}\text { Buang- } \\
\text { buang }\end{array}$ & $\begin{array}{l}\text { This is usually done at the first midnight after the } \\
\text { retum home event }\end{array}$ \\
\hline Balik tikar & $\begin{array}{l}\text { The mat on the bed is reversed along with the } \\
\text { mattress, the bride } 3 \text { nights in the men's house }\end{array}$ \\
\hline $\begin{array}{l}\text { Jamuan } \\
\text { makan } \\
\text { saprah }\end{array}$ & $\begin{array}{l}\text { Typical Malay banquets conducted in groups by } \\
\text { sitting cross-legged on the floor as many as } 6 \text { people. }\end{array}$ \\
\hline Tarup & Tents where a banquet \\
\hline $\begin{array}{l}\text { Tepung } \\
\text { tawar }\end{array}$ & $\begin{array}{l}\text { To ask for salvation and to avoid something } \\
\text { mdesirable, which is certainly shown to God } \\
\text { Almighty }\end{array}$ \\
\hline Ngukor & Statement of weight, length, and time \\
\hline Pacoan & $\begin{array}{l}\text { Social gathering for wedding events based on certain } \\
\text { goods and who get it at the time of maniage }\end{array}$ \\
\hline
\end{tabular}

Linkages of Malay Local Wisdom Sambas, Mathematical Connection and Strengthening Character Education

Some local wisdom ethnic Malay Sambas obtained by documentation, interviews, and questionnaires on some respondents namely Melas Sambas community leaders and teachers of mathematics. A questionnaire containing the aspect of Malay wisdom of Sambas Malay who was once revealed at a local cultural event was obtained from interviews with some traditional leaders. While the mathematics learning associated with local wisdom obtained mathematics teacher information through questionnaires, interviews, and documentation.

From some local wisdom described in Table 1, then traced between local wisdom that is considered relevant and has relevance to learning mathematics in junior high. By using documentation, questionnaires and interview results obtained findings such as the following table. Further triangulation is done to obtain linkages between these aspects that are considered quite relevant in learning mathematics.

\section{Research Discussion}

The kinship system can be seen clearly in large families. Large families can be tied up and turned on in events such as wedding receptions, family gatherings, thanksgiving, fresh flour and so on. Nevertheless, the event goes as it is, without written documentation. If done documentation, only in the form of photos. Archiving is clearly underestimated, eg a family treatise with a complete name using a bin. Moral messages that arise when the family kinship is held is togetherness, mutual respect, care for the environment and social care. The concept of mathematics can be expressed in the set. Because the family tree was shown can be defined firmly in a particular set, so that the intended members can enter or not from the family.

Cikram is a sign of engagement between two people. The engagement bond is known and approved by each parent. The bonding was done because the two teenagers had already happened introductions and wanted to a more serious level of marriage. The bond is usually marked with a ring. Through the ring is a mathematical concept that can be developed ie the circle. The ring is the realization of one of the mathematical connections for the matter of the circle. Social care in question is a ring as a binder of social relations between two individuals who come from two families.

Antar betang can be interpreted as delivery of goods. Antar betang made one part of the wedding procession. In the past, the two bride and groom did not know each other so inter pinang quite complicated in the implementation, due to matchmaking parents. Currently inter pinang one of the activities of the ability of men and women as the implementation. The moral message contained in the activity is a sense of responsibility and independence. But the implementation process itself cares about social and environmental tilted conditioned. Through the goods that become the delivery is one picture of the independence of a man and also a measure of sense of responsibility physically. Associated with mathematical connections then the event sees the various forms of delivery goods are the realization of geometric concepts and the sum and size of goods according to requirements is a counting operation in mathematics. The application of the summing concept is the addition of multiple operations. This means the sum of several items that link units such as dozen, kodi, unit length and one weight.

The marriage is also said to be a reception. Through this celebration event allows the gathering of family members who are far or near. So in these activities can be the introduction of each member of one family to another, happening salam-shake marks of kinship and intimacy. The revealed moral message of togetherness, mutual respect, and friendship. Effects indirectly arise social awareness. While the relevant mathematical concepts are set and probability.

Nasek peace is a meal together with a pair of brides after the match. The procession of the activities of the peacekeeping meal with the stages that have been arranged. The bridegroom first new bride. As well as the women give bribes on the part of men. The steps are from the existing dish, first take the rice, and side dishes with vegetables or sauce. The bride feeds into the bridegroom, and vice versa. Noting the ordinances of peace rice, it turns out that each stage symbolizes a certain moral message. Beginning with rice, because after all rice is the main food. It means that wives in life are expected to know to sort between the main and the complement. Bribe each represents learning to solve the problems of life together and social concerns more highlighted. Mathematical connections that can be raised here include the theory of the opportunity of taking the type of dish.

Turning mats is an activity event for the bride after the first night passed. Most of the brides before the 60s, found by matchmaking. As a result, the bride has not known each other so to be shy. To reduce the shyness is placed side by side which is limited by the roll of the mat. Resulting in the bride is conditioned to be more familiar. The moral message that emerges is togetherness and mutual respect. 
Clearly also has an effect on social care. Relevant mathematical concepts are to wake flat, build side curved space, volume, area, and some other geometric concepts.

Saprahan dinner or meal besaprah ie eating together as many as 6 people in a sitting position on the floor. This means that the available dishes should be as many as 6 pieces, while the variety of side dishes there are 5 kinds, there are 2 spoons as well as while the rice is the staple food is in a large bowl (basin). All symbols of the numbers have their respective meanings. According to the early introduction of saprahan occurred at the time of king Sambas who have the idea that people remember and obey the worship by way of eating habits together. For that, the king reminded about the pillars of faith by eating together as many as 6 people, various side dishes, and kuahnya as much as 5 varieties that describe the pillars of Islam, and spoon prepared as much as 2 pieces that represent 2 times masyahadat. While a basin containing rice shows a leader who is ready to protect each member of his group. In the presentation of the saprahan dish, the waiter is 6 people sorted in the dish. The first waiter arranges the saprahan area and the order of saprahan that must be fulfilled. The second waiter brought hand-washing water and dishes. The third waiter brought rice. The fourth waiter brings a side dish and vegetables. The fifth waiter brings a drink of water.

Belallek ie completing work in groups and taking turns for each member of the group. The work in question usually occurs in settling rice fields, because between the time of grass and plant seeds should not be in the old wantu. For example, Ahmad has a 1 hectare paddy field and the existing grass will be done by 10 people including Pak Ahmad and takes 2 days. This means that Ahmad is ready to clean up the rice field for the other ( 9 people) at another time with 2 days for each of those fields. Moral messages contained in the activities belallek is gotong royong, togetherness,

Pacoan is an social gathering for weddings or other parties based on certain goods and who get it at the time of marriage. Pacoan system is similar to social gathering, the difference is there is no unplugging system. Pacoan name is adjusted to the name of the goods. For example, meat pacoan as much as $5 \mathrm{~kg}$ between Ahmad, Bujang and 8 others. The rule of the game is that if Ahmad has a party or a crowd, then Bujang and the other 8 are obliged to hand over $5 \mathrm{~kg}$ of meat each to Ahmad. Likewise, if during his time Bujang throws a party, then Ahmad and 8 other friends are obliged to hand over $5 \mathrm{~kg}$ of meat each to Bujang. This means each member of the meat pacoan gets as much as $45 \mathrm{~kg}$ from the other members. Associated with mathematics learning then the mathematical concepts that can be invested include summation and probability. While the moral message contained in it namely responsibility and mutual cooperation. Responsibility arises as a result of mutual bearing the mandate. While gotongroyong because the problem solving is done with the same lightweight principle and carry the same weight.

Of the eleven kinds of local wisdom of Melayu Sambas ethnic, it turns out that has relevance to the mathematical connection that is kinship system, cikram, antar pinang, execution of marriage, waste, turning mat, saprahan, tarup, flour, and belalek. While ngukor and pacoan quite weak in terms of relevance to the mathematical connection. Nevertheless, all local Malay wisdom ethnic Malay Sambas each have a contribution in strengthening character education.

\section{CONCLUSIONS}

The result of the research shows that there are 12 local wisdom of Melayu Sambas ethnic that ever exist in social life, and that is still realized 10 local wisdom (except ngukor and pacoan). While the local wisdom of Malay Sambas ethnic who have relevance to the mathematical connection and strengthening the education of social and environmental care characters there are 10 kinds. To categorize and pacoan pertained weak connection relevance.

\section{REFERENCES}

Bergeron, J. and Herscovics, N. (2000). Psychological Aspects of Learning Early Arithmetic." In P. Nesher and J. Kilpatrick (eds.) Mathematics and Cognition. Cambridge: Cambridge University Press.

Dimyati dan Mudjiono. (1994). Belajar dan Pembelajaran. Jakarta: P2LPTK.

Dwi, Astuti and Bambang, Hudiono (2009). Perilaku Metakognisi Anak dalam Matematika: Kajian Berdasarkan Etnis dan Gender pada Siswa SMP di Kalimantan Barat. Seminar Nasional Matematika dan Pendidikan Matematika 2009. ISSN 978-979-16353-3-2

National Council of Teacher of Mathematics (2000). Principles and Standard for School Mathematics. Reston, V.A: NCTM.

Phongphit, Seri, and Wichit Nantasuwan. (2002). Master Community Plan: People Research and Development. Bangkok:Charoenwit.

Setyawan, Andoko Ageng (2013). Penerapan Model Pembelajaran Connecting-Organizing-ReflectingExtending (CORE) untuk Meningkatkan Kemampuan Pemahaman dan Koneksi Matematis Siswa SMA: Penelitian Kuasi Eksperimen terhadap Siswa SMA di Duri. S2 thesis, Universitas Pendidikan Indonesia.

Singarimbun, Masri dan Sofian Effendi. (1999). Metode Penelitian Survey (Edisi Revisi). LP3ES. Jakarta.

Srihayati. (2011). Menggali Nilai-nilai Kearifan Lokal dalam Mempertahankan Karakter Peduli Lingkungan pada Pembelajaran IPS, Prosiding Konvensi Nasional Pendidikan IPS (Konaspipsi) Ke-1, ISBN : 978-602-98674-1-1, hal 214-235/1314 Juli 2011. 